\title{
Disclosure Quality in Goodwill Impairment Tests: Turkey Case
}

\author{
Sevin Gurarda \\ Gediz University, İzmir, Turkey
}

\begin{abstract}
The issue of goodwill impairment has been debated in many countries throughout the world. Adoption of International Financial Reporting Standards (IFRS) introduced fundamental changes in accounting and impairment methods for goodwill. Since global stock markets went into decline in 2008, there has been much debate over the issue of goodwill impairment in the US and European stock exchange markets, especially on how large the write-downs should be. Complexity of International Accounting Standards (IAS) and IFRS focusing on goodwill and goodwill impairment techniques may lead to inconsistent compliance and varying levels of disclosure quality. The aim of this study is to analyze goodwill impairment during and after the recent financial crisis for companies listed on the Borsa Istanbul (BIST) 100 index and to assist the financial statement users in the assessment of disclosure quality under IAS 36, Paragraph 134d. Tools such as: (1) the period over which management has projected cash flows; (2) the growth rate used for cash flow projections; (3) the discount rate(s) applied to projections; and (4) methods employed to determine recoverable amount are analyzed. Insufficient disclosures on these tools are observed. The findings are of interest to researchers examining the implication of IAS 36, regulators, and policy-setters.
\end{abstract}

Keywords: goodwill impairment, International Accounting Standards (IAS) 36, disclosure quality

\section{Introduction}

The financial reporting practices of companies are varying in different countries. This leads to great complications for those auditing and interpreting published financial statements. In order to deal with this problem, organizations in different parts of the world have to harmonize and standardize national accounting standards with international standards. Current and potential investors desire to compare the information published by a target company with its competitors in their home countries or/and other parts of the world. For those reasons, countries which adopt internationally recognized accounting standards for financial reporting will be positioned at a significant advantage to those who do not.

The global accounting standards have been publicly supported by many international organizations, including the G20 (The Group of 20 Finance Ministers and Central Bank Governors form from 20 major economies), World Bank, International Monetary Fund, Basel Committee, International Organization of Securities Commissions, etc.. More than 100 countries around the world require International Accounting Standards (IAS)/International Financial Reporting Standards (IFRS) reporting for all domestic listed companies (Gurarda, 2015).

Sevin Gurarda, assistant professor, vice head, Department of Management, Faculty of Economics and Administrative Sciences, Gediz University. Email: sevin.gurarda@gediz.edu.tr. 
IAS and IFRS are created for serving the need of common language in accounting and financial statements. With the adoption of IFRS, one of the expectations of financial statement users is further transparency and useful information for decision-making. All of these expectations point out fair value presentation in financial statements. One of the standards that contribute fair value is IAS 36.

The objective of IAS 36, according to the International Accounting Standards Board (IASB), is to prescribe the procedures which an entity applies to ensure that its assets are carried at no more than their recoverable amount. An asset is carried at more than its recoverable amount if it carries amount that exceeds the amount to be recovered through use or sale of the asset. If this is the case, the asset is described as impaired and the standard requires the entity to recognize an impairment loss. The standard also specifies when an entity should reverse an impairment loss and prescribes disclosures.

Although the main principles of IAS 36 are very clear, the practical application of IAS 36 has always been challenging and problems have unearthed during the recent economic uncertainty.

Since global stock markets went into decline in 2008, there has been much debate over the issue of goodwill impairment in the US and European stock exchange markets, especially on how large the write-downs should be. During the financial crisis in $2008,68 \%$ of 2,500 publicly-held companies wrote down goodwill by taking impairment charges and the total charges were $\$ 260$ billion (Holtzman \& Sinnett, 2009).

According to the report of Ernst \& Young (2011), goodwill impairment disclosure is a requirement, as much as an opportunity and a danger. The key question is whether sufficient disclosure has been made about the uncertainty of the impairment calculation. This is an interesting question in the financial crisis period. Do companies announce insufficient disclosure about goodwill impairment tests to safeguard their stock prices? This is the main leitmotiv to prepare this paper. Therefore, the goodwill impairment during the recent financial crises for companies listed on the BIST 100 index, in order to examine the disclosure quality of Turkish firms on goodwill assessment, is analyzed. This paper is organized as follows: Following the introduction, the second section gives information about the requirements of IAS 36; the third section presents the previous studies, whereas the fourth section consists of data and findings; and the last section concludes this paper.

\section{Requirements of IAS 36}

The objective of this standard is to prescribe the procedures which an entity applies to ensure that its assets are carried at no more than their recoverable amount. An asset is carried at more than its recoverable amount if its carrying amount exceeds the amount to be recovered through use or sale of the asset. If this is the case, the asset is described as impaired and the standard requires the entity to recognize an impairment loss.

The standard also specifies when an entity should reverse an impairment loss and prescribes disclosures (IAS 36, Paragraph 134):

"An entity shall disclose the information required by (a)-(f) for each cash-generating unit (group of units) for which the carrying amount of goodwill or intangible assets with indefinite useful lives allocated to that unit (group of units) is significant in comparison with the entity's total carrying amount of goodwill or intangible assets with indefinite useful lives:

(a) The carrying amount of goodwill allocated to the unit (group of units).

(b) The carrying amount of intangible assets with indefinite useful lives allocated to the unit (group of units). 
(c) The basis on which the unit's (group of units') recoverable amount has been determined (i.e., value in use or fair value less costs to sell).

(d) If the unit's (group of units') recoverable amount is based on value in use:

(i) A description of each key assumption on which management has based its cash flow projections for the period covered by the most recent budgets/forecasts. Key assumptions are those to which the unit's (group of units') recoverable amount is most sensitive.

(ii) A description of management's approach to determining the value(s) assigned to each key assumption, whether those value(s) reflect past experience or, if appropriate, are consistent with external sources of information, and, if not, how and why they differ from past experience or external sources of information.

(iii) The period over which management has projected cash flows based on financial budgets/forecasts approved by management and, when a period greater than five years is used for a cash-generating unit (group of units), an explanation of why that longer period is justified.

(iv) The growth rate used to extrapolate cash flow projections beyond the period covered by the most recent budgets/forecasts, and the justification for using any growth rate that exceeds the long-term average growth rate for the products, industries, or country or countries in which the entity operates, or for the market to which the unit (group of units) is dedicated.

(v) The discount rate(s) applied to the cash flow projections.

(e) If the unit's (group of units') recoverable amount is based on fair value less costs to sell, the methodology used to determine fair value less costs to sell. If fair value less costs to sell is not determined using an observable market price for the unit (group of units), the following information shall also be disclosed:

(i) A description of each key assumption on which management has based its determination of fair value less costs to sell. Key assumptions are those to which the unit's (group of units') recoverable amount is most sensitive.

(ii) A description of management's approach to determining the value (or values) assigned to each key assumption, whether those values reflect past experience or, if appropriate, are consistent with external sources of information, and, if not, how and why they differ from past experience or external sources of information.

If fair value less costs to sell is determined using discounted cash flow projections, the following information shall also be disclosed:

(iii) The period over which management has projected cash flows.

(iv) The growth rate used to extrapolate cash flow projections.

(v) The discount rate(s) applied to the cash flow projections.

(f) If a reasonably possible change in a key assumption on which management has based its determination of the unit's (group of units') recoverable amount would cause the unit's (group of units') carrying amount to exceed its recoverable amount:

(i) The amount by which the unit's (group of units') recoverable amount exceeds its carrying amount.

(ii) The value assigned to the key assumption.

(iii) The amount by which the value assigned to the key assumption must change, after incorporating any consequential effects of that change on the other variables used to measure recoverable amount, in order for the unit's (group of units') recoverable amount to be equal to its carrying amount". 


\section{Previous Studies}

Goodwill and sufficient goodwill impairment test disclosures in line with IAS 36 are important for investors to understand financial health of the company. Disclosures and quality of disclosures regarding goodwill are examined.

The European Securities and Markets Authority (ESMA) looks into the accounting practices of a sample of 235 European issuers from 23 countries and reports that significant impairment losses of goodwill were limited to a handful of issuers according to 2011 IFRS Financial Statements. ESMA recommends the issuers of financial statements to: (1) better specify the key assumptions used in the impairment test; (2) include sensitivity analyses with sufficient detail and transparency, especially in situations when indicators are present that impairment might have occurred; (3) determine the growth rates used to extrapolate cash flow projections based on budgets and forecasts; and (4) disclose specific discount rates for each material cash-generating unit rather than average discount rates.

Andrews (2006) assessed the extent of asset impairment losses disclosed by companies listed on the Financial Times Stock Exchange (FTSE) 350 index using published financial reports available in 2004. A sample of 79 companies is found to have charged an impairment loss. This research has interesting results. According to the research results, 58 out of 79 companies (73\%) report an impairment of goodwill, $62 \%$ of companies in the sample do not disclose a specific accounting policy note about how the impairment loss is calculated, and $40 \%$ of companies in the sample do not disclose a reason for the impairment loss.

By focusing on the Australian market, Carlin, Finch, and Ford (2007) analyzed impairment of assets and the quality of disclosure according to IAS 36 by reviewing the 2006 accounts of a sample of 50 large Australian listed corporations. According to their research, 37 of 50 firms in the research sample use value in use method. Only eight firms adopt a fair value methodology for estimating recoverable amount. Another result is that in approximately $36 \%$ of the observed cases, the discount rate disclosures provided by sample firms are effectively useless for the purpose of facilitating an independent analysis of the impairment testing process. A total of 23 from 39 firms which used the value in use method (and were thus required to make explicit details of growth assumptions used in the modeling process (two firms using mixed method are added)) fail to provide information which will assist external analysts in undertaking a basic independent assessment of the impairment testing process. Only $15 \%$ of the observed firms disclose growth rate assumptions in a manner fully consistent with the framework dictated by Australian Accounting Standards Board 136.

The low level in compliance with IAS 36 may be related to a negative reaction of the capital market to the announcement of goodwill impairment. Li, Shroff, Venkataraman, and Zhang (2010) examined whether the market reacts negatively to the announcement of a goodwill impairment loss by calculating cumulative abnormal returns over a three-day window centered on the announcement date during the period of 1996-2006. Their evidence shows that investors as well as financial analysts revise their expectations downward on the announcement of a goodwill impairment loss, and this downward revision is related to the magnitude of the loss. Xu, Anandaraja, and Curatola (2011) also found out that goodwill charges are negatively viewed by investors, on average, but financial health moderates the relation.

Another issue about goodwill and its impairment process is the intention of the management. Do managements of firms believe that asset write-offs will signal less profitability or do they believe that they are aware of assets with low performance and do they clear these assets by write-offs? Elliott and Shaw (1988) 
observed the period from 1982 to 1985 using a sample of 240 US companies that have disclosed an asset write-down. They measured financial performance in terms of returns on assets and returns on equity. They found that those companies with write-downs perform worse than those without write-downs. Zucca and Campbell's (1992) results confirm that write-downs are being used to manage earnings. They also found that there is no significant evidence of a positive stock market reaction to the write-down announcement. According to Zucca and Campbell (1992), there are two possible patterns of earnings management during the period in which the write-down is announced: income smoothing and big baths. Income smoothing describes an earnings pattern in which the management aspires to maintain a steady and predictable rate of earnings growth. The management may try to record discretionary gains, losses, or accruals in the period which will best help them to attain their goal of steady growth. The second form of earnings management has been referred to as big bath. Under this scenario, the firm appears to save up discretionary losses or accruals and then records several of them in the same period or in a period in which the firm has already experienced below normal earnings. Management might undertake a big bath to signal investors that bad times are behind them and better times will follow.

\section{Data and Findings}

The objective of this paper is to assess the disclosure quality in goodwill impairment for the period of 2008-2012. Firms listed on the BIST 100 index are selected as sample and year-end financial statements with disclosures for BIST 100 companies are analyzed. Once the published financial statements were collected, financial statements for goodwill account and related disclosures have been read. ${ }^{1}$

Table 1 shows the breakdown of the companies according to the sectors where they operate.

Table 1

Classification of Companies by Sectors

\begin{tabular}{|c|c|c|c|c|c|}
\hline \multirow{2}{*}{ Sector } & \multicolumn{5}{|c|}{ Number of firms } \\
\hline & 2008 & 2009 & 2010 & 2011 & 2012 \\
\hline Communication & 2 & 2 & 2 & 2 & 2 \\
\hline Consumer trade & 1 & 1 & 1 & & \\
\hline Construction and public works & 1 & 1 & 1 & 2 & 1 \\
\hline Electricity, gas, and water & 2 & 1 & & 1 & 1 \\
\hline Information technology & 1 & 0 & & 1 & 1 \\
\hline Chemicals, rubber, and plastic & 5 & 6 & 5 & 3 & 3 \\
\hline Fabricated metal products, machinery, and equipment & 2 & 2 & 3 & 2 & 3 \\
\hline Food, beverage, and tobacco & 4 & 4 & 3 & 3 & 3 \\
\hline Non-metallic products & 3 & 1 & 1 & 2 & 1 \\
\hline Paper and paper products, printing, and publishing & 3 & 4 & 4 & 4 & 3 \\
\hline Mining & 1 & 1 & 1 & 1 & 1 \\
\hline Other manufacturing industries & 0 & 0 & & 1 & 1 \\
\hline Restaurants and hotels & 1 & 1 & & & \\
\hline Transportation & & & 1 & & \\
\hline Wholesale trade & 1 & 1 & 1 & 1 & 1 \\
\hline Total & 27 & 25 & 23 & 23 & 21 \\
\hline
\end{tabular}

${ }^{1}$ Financial institutions including banks and participation banks, insurance companies, financial leasing and factoring companies, holding and investment companies, investment trusts, real estate investment trusts, venture capital investment trusts, and brokerage houses are excluded. 
Comparative/evaluative method as mentioned by Carlin and Finch (2011) is employed. This method examines the tools such as: the period over which management has projected cash flows; the growth rate used to extrapolate cash flow projections; the discount rate(s) applied to the cash flow projections; and the methods employed to determine recoverable amount in order to assess the disclosures of our sample firms.

Table 2

Percentage of Goodwill in Total Assets

\begin{tabular}{lrrrrr}
\hline \multirow{2}{*}{ Sector } & \multicolumn{5}{c}{ Goodwill/total assets (\%) } \\
\cline { 2 - 6 } & 2008 & 2009 & 2010 & 2011 & 2012 \\
\hline Communication & 1.2 & 1.7 & 0.9 & 0.3 & 0.2 \\
Consumer trade & 39.7 & 42.4 & 40.4 & 10.0 & 40.0 \\
Construction and public works & 1.5 & 1.4 & 1.6 & 41.1 & 0.8 \\
Electricity, gas, and water & 2.4 & 6.2 & - & 0.4 & 0.3 \\
Information technology & & 2.5 & - & 6.3 & 5.4 \\
Chemicals, rubber, and plastic & 23.4 & 24.8 & 11.6 & 2.8 & 1.6 \\
Fabricated metal products, machinery, and equipment & 2.1 & 2.0 & 2.2 & - & 32.4 \\
Food, beverage, and tobacco & 0.2 & 0.3 & 9.7 & - & 14.0 \\
Non-metallic products & 11.1 & 9.8 & 0.1 & 0.6 & 0.1 \\
Paper and paper products, printing, and publishing & 12.5 & 13.9 & 7.5 & 3.3 & 2.4 \\
Mining & 1.2 & 6.6 & 2.6 & 1.3 & 0.9 \\
Other manufacturing industries & 8.6 & - & - & 10.7 & 10.5 \\
Restaurants and hotels & - & 6.3 & - & - & - \\
Transportation & - & - & 4.1 & - & - \\
Wholesale trade & 1.2 & 1.5 & 0.7 & 10.0 & - \\
\hline
\end{tabular}

As seen in Table 2, the highest goodwill/total assets ratio is seen in consumer trade in 2008, 2009, and 2012. In 2011, it is observed in construction and public works.

Table 3

Information About Goodwill Impairment Tests (Global Financial Crisis Period)

\begin{tabular}{|c|c|c|c|c|c|c|}
\hline \multirow[b]{2}{*}{ Sector } & \multicolumn{3}{|c|}{2008} & \multicolumn{3}{|c|}{2009} \\
\hline & $\begin{array}{l}\text { Info. for } \\
\text { test }\end{array}$ & $\begin{array}{l}\text { No info. } \\
\text { for test }\end{array}$ & $\begin{array}{l}\text { Info. for } \\
\text { method }\end{array}$ & $\begin{array}{l}\text { Info. for } \\
\text { test }\end{array}$ & $\begin{array}{l}\text { No info. } \\
\text { for test }\end{array}$ & $\begin{array}{l}\text { Info. for } \\
\text { method }\end{array}$ \\
\hline Communication & 2 & & 1 & 2 & & 1 \\
\hline Consumer trade & 1 & & & 1 & & \\
\hline Construction and public works & 1 & & 1 & 1 & & 1 \\
\hline Electricity, gas, and water & 2 & & 1 & 1 & & 1 \\
\hline Information technology & 1 & & & 0 & & \\
\hline Chemicals, rubber, and plastic & 4 & 1 & 2 & 4 & 2 & 1 \\
\hline Fabricated metal products, machinery, and equipment & 1 & 1 & 2 & 2 & & 2 \\
\hline Food, beverage, and tobacco & 4 & & & 3 & 1 & 1 \\
\hline Non-metallic products & 3 & & & 1 & & 1 \\
\hline Paper and paper products, printing, and publishing & 3 & & & 4 & & 2 \\
\hline Mining & 0 & 1 & & 1 & & \\
\hline Other manufacturing industries & 0 & & & 0 & & \\
\hline Restaurants and hotels & 0 & 1 & & 1 & & \\
\hline Wholesale trade & 1 & & 1 & 1 & & \\
\hline Total & 23 & 4 & 8 & 22 & 3 & 10 \\
\hline
\end{tabular}


Assumptions such as discount rates, growth rates, cash flow assumptions, and risk sensitivity analysis are main tools to understand goodwill reporting regime not only for selected companies and sectors but also for the country. Unfortunately in Turkey in 2008, as Table 3 above shows, only eight of 27 firms have an effective disclosure about the method they have used in the goodwill impairment test. The dominant method among the eight firms is the value in use method. Only one firm chose the fair value methodology. Four firms in 2008 disclosed nothing about the goodwill impairment test. If firms disclosed methods and firms without any information are excluded, 11 firms satisfied only by citing that "Goodwill impairment test was performed" without giving any further information. In 2009, information about methodology and at least about performing a goodwill impairment test increased, but it was still limited and unfortunately, it did not allow any meaningful evaluation.

For the years of 2010-2011 and 2012, the dominant method used is the value in use method. As seen from Table 4, five firms in 2010 disclosed nothing about the goodwill impairment test. In 2011, firms informing the test have increased to 19 out of 23. In 2012, the sample consists of 21 firms, and 16 of them gave information about the goodwill impairment test.

Table 4

Information About Goodwill Impairment Tests (After Global Financial Crisis)

\begin{tabular}{|c|c|c|c|c|c|c|c|c|c|}
\hline \multirow[b]{2}{*}{ Sector } & \multicolumn{3}{|c|}{2010} & \multicolumn{3}{|c|}{2011} & \multicolumn{3}{|c|}{2012} \\
\hline & $\begin{array}{l}\text { Info. for } \\
\text { test }\end{array}$ & $\begin{array}{l}\text { No info. } \\
\text { for test }\end{array}$ & $\begin{array}{l}\text { Info. for } \\
\text { method }\end{array}$ & $\begin{array}{l}\text { Info. for } \\
\text { test }\end{array}$ & $\begin{array}{l}\text { No info. } \\
\text { for test }\end{array}$ & $\begin{array}{l}\text { Info. for } \\
\text { method }\end{array}$ & $\begin{array}{l}\text { Info. for } \\
\text { test }\end{array}$ & $\begin{array}{l}\text { No info. } \\
\text { for test }\end{array}$ & $\begin{array}{l}\text { Info. for } \\
\text { method }\end{array}$ \\
\hline Communication & 2 & & 2 & 2 & & 2 & 2 & & 2 \\
\hline Consumer trade & 1 & & 1 & & & & & & \\
\hline Construction and public works & 1 & & 1 & 1 & 1 & & 1 & & 1 \\
\hline Electricity, gas, and water & & & & 1 & & & 1 & & \\
\hline Information technology & & & & 1 & & & & 1 & \\
\hline Chemicals, rubber, and plastic & 5 & & 4 & 2 & 1 & 2 & 3 & & 3 \\
\hline $\begin{array}{l}\text { Fabricated metal products, } \\
\text { machinery, and equipment }\end{array}$ & 2 & 1 & 2 & 2 & & 2 & 3 & & 3 \\
\hline Food, beverage, and tobacco & 2 & 1 & 1 & 3 & & 1 & 2 & 1 & 2 \\
\hline Non-metallic products & & 1 & & 1 & 1 & & 1 & & \\
\hline $\begin{array}{l}\text { Paper and paper products, } \\
\text { printing, and publishing }\end{array}$ & 3 & 1 & 2 & 4 & & 4 & 2 & 1 & 2 \\
\hline Mining & 1 & & 1 & 1 & & 1 & 1 & & 1 \\
\hline Other manufacturing industries & & & & & 1 & & & 1 & \\
\hline Restaurants and hotels & & & & & & & & & \\
\hline Transportation & 1 & & & & & & & & \\
\hline Wholesale trade & & 1 & & 1 & & 1 & & 1 & \\
\hline Total & 18 & 5 & 14 & 19 & 4 & 13 & 16 & 5 & 14 \\
\hline
\end{tabular}

According to IAS 36, firms adopting the value in use method are required to disclose the period over which management projects cash, the discount rate, and the growth rate. Becoming effective on January 1, 2009, firms adopting the fair value method shall also disclose disclosures written in Part 2.

Discount rates, growth rates, and the projected cash flow period are strong signals about the perception and assessment of a firm's management for risk. Discount rate disclosures provide strong signals in relation to management's assessment of risk profile and growth rate signals the degree of optimism and pessimism around the future business prospects (Carlin \& Finch, 2011). 
According to Table 5 below, there is a wide range in discount rate in 2008 and 2009. In 2008, the range is from $9.70 \%$ to $18.30 \%$. In 2009 , it is from $6 \%$ to $16.46 \%$. In industry grouping, there is a minor difference in 2008 and 2009. For growth rate, the range in 2008 is from $2 \%$ to $6 \%$, in 2009 , it is from $2 \%$ to $5 \%$. Low discount rates will result in overestimated cash flow projections and potential goodwill impairment losses will be deferred or avoided. Growth rate disclosures, such as $5 \%$ and $6 \%$, are very optimistic disclosures especially in the financial crisis period. For every year, there is a wide range in growth rate. To have a higher growth rate may be a signal of optimist risk assessment.

Table 5

Range of Growth Rate and Discount Rate

\begin{tabular}{|c|c|c|c|c|c|c|c|c|c|c|}
\hline \multirow[b]{2}{*}{ Sector } & \multicolumn{2}{|c|}{2008} & \multicolumn{2}{|c|}{2009} & \multicolumn{2}{|c|}{2010} & \multicolumn{2}{|c|}{2011} & \multicolumn{2}{|c|}{2012} \\
\hline & $\begin{array}{l}\text { Growth } \\
\text { rate }(\%)\end{array}$ & $\begin{array}{l}\text { Discount } \\
\text { rate }(\%)\end{array}$ & $\begin{array}{l}\text { Growth } \\
\text { rate }(\%)\end{array}$ & $\begin{array}{l}\text { Discount } \\
\text { rate }(\%)\end{array}$ & $\begin{array}{l}\text { Growth } \\
\text { rate }(\%)\end{array}$ & $\begin{array}{l}\text { Discount } \\
\text { rate }(\%)\end{array}$ & $\begin{array}{l}\text { Growth } \\
\text { rate }(\%)\end{array}$ & $\begin{array}{l}\text { Discount } \\
\text { rate }(\%)\end{array}$ & $\begin{array}{l}\text { Growth } \\
\text { rate }(\%)\end{array}$ & $\begin{array}{l}\text { Discount } \\
\text { rate }(\%)\end{array}$ \\
\hline Communication & & & $3.4-3.5$ & $14-15$ & $2.5-3.4$ & $14.5-15.8$ & $0.35-2.8$ & $13.7-15.5$ & $12.5-16.10$ & 3 \\
\hline Consumer trade & & & & 6 & & 5.9 & & 9.5 & & \\
\hline $\begin{array}{l}\text { Construction and } \\
\text { public works } \\
\text { Electricity, gas, and } \\
\text { water } \\
\text { Information } \\
\text { technology }\end{array}$ & & & 4 & 14 & 3 & 12 & & & & \\
\hline $\begin{array}{l}\text { Chemicals, rubber, } \\
\text { and plastic }\end{array}$ & $2-6$ & $9.70-10.36$ & 5 & 10 & $2-9$ & $8.28-18$ & & 12.7 & $1-7$ & $8.9-20$ \\
\hline $\begin{array}{l}\text { Fabricated metal } \\
\text { products, } \\
\text { machinery, and } \\
\text { equipment }\end{array}$ & & & 3 & 9 & 2.5 & $9-12$ & 2.5 & $9.86-9$ & 3 & $9-18$ \\
\hline $\begin{array}{l}\text { Food, beverage, } \\
\text { and tobacco }\end{array}$ & & & 3 & & 3 & 13.05 & 3 & 14.7 & $1-3$ & $6.7-13.9$ \\
\hline $\begin{array}{l}\text { Non-metallic } \\
\text { products }\end{array}$ & & & & 13 & & & & & & \\
\hline $\begin{array}{l}\text { Paper and paper } \\
\text { products, printing, } \\
\text { and publishing }\end{array}$ & & & 2 & 12 & 7.05 & 24 & & 11.1 & & \\
\hline Mining & & & & & & & & & & \\
\hline $\begin{array}{l}\text { Other } \\
\text { manufacturing } \\
\text { industries } \\
\text { Restaurants and } \\
\text { hotels }\end{array}$ & & & & 16 & & & & & & \\
\hline Transportation & & & & & 1 & 12.2 & & & & \\
\hline Wholesale trade & 3.4 & 18.30 & & & & & & & & \\
\hline
\end{tabular}

Note. The rate shows the minimum and maximum rates in each sector.

According to the standard, when a period greater than five years is used for a cash-generating unit (group of units), an explanation of why that longer period is justified must be disclosed. According to Table 6 below, in 2008, only one firm gave information about the period of cash flows. Except 2009, the number of firms which disclosed information about cash flow has increased. The ranges for the period vary between five and 15 years, but as written in IAS $36^{2}$ (IAS 36.35 and IAS 36.34), the explanation for the justified period that is more than five years has not been disclosed for any year.

${ }^{2}$ Retrieved from http://ec.europa.eu/internal_market/accounting/docs/consolidated/ias36_en.pdf. 
Table 6

Information About Budget Assumptions

\begin{tabular}{|c|c|c|c|c|c|c|c|c|c|c|}
\hline \multirow[b]{2}{*}{ Sector } & \multicolumn{2}{|c|}{2008} & \multicolumn{2}{|c|}{2009} & \multicolumn{2}{|c|}{2010} & \multicolumn{2}{|c|}{2011} & \multicolumn{2}{|c|}{2012} \\
\hline & $\begin{array}{l}\text { Budgeted } \\
\text { year }\end{array}$ & $\begin{array}{l}\text { Cash } \\
\text { flow }\end{array}$ & $\begin{array}{l}\text { Budgeted } \\
\text { year }\end{array}$ & $\begin{array}{l}\text { Cash } \\
\text { flow }\end{array}$ & $\begin{array}{l}\text { Budgeted } \\
\text { year }\end{array}$ & $\begin{array}{l}\text { Cash } \\
\text { flow }\end{array}$ & $\begin{array}{l}\text { Budgete } \\
\text { year }\end{array}$ & $\begin{array}{l}\text { Cash } \\
\text { flow }\end{array}$ & $\begin{array}{l}\text { Budgeted } \\
\text { year }\end{array}$ & $\begin{array}{l}\text { Cash } \\
\text { flow }\end{array}$ \\
\hline Communication & & & $7-15$ years & & 5 years & & $\begin{array}{l}8-20 \\
\text { years }\end{array}$ & & $7-15$ years & \\
\hline Consumer trade & & & 5 years & & 5 years & 5 years & & & 5 years & \\
\hline $\begin{array}{l}\text { Construction } \\
\text { and public } \\
\text { works } \\
\text { Electricity, gas, } \\
\text { and water } \\
\text { Information } \\
\text { technology }\end{array}$ & & & 5 years & & 5 years & & 5 years & & & \\
\hline $\begin{array}{l}\text { Chemicals, } \\
\text { rubber, and } \\
\text { plastic }\end{array}$ & & & 5 years & & 10 years & 10 years & & & $\begin{array}{l}\text { Yearly-5 } \\
\text { years }\end{array}$ & 10 years \\
\hline $\begin{array}{l}\text { Fabricated metal } \\
\text { products, } \\
\text { machinery, and } \\
\text { equipment }\end{array}$ & 5 years & 3 years & $4-5$ years & & 5 years & & 5 years & & 5 years & 5 years \\
\hline $\begin{array}{l}\text { Food, beverage, } \\
\text { and tobacco }\end{array}$ & & & & & 3 years & 10 years & 3 years & 10 years & 3 years & $\begin{array}{l}3-10 \\
\text { years }\end{array}$ \\
\hline $\begin{array}{l}\text { Non-metallic } \\
\text { products }\end{array}$ & & & 10 years & & & & & & 7 years & \\
\hline $\begin{array}{l}\text { Paper and paper } \\
\text { products, } \\
\text { printing, and } \\
\text { publishing }\end{array}$ & & & & & 5 years & 5 years & 5 years & 5 years & 5 years & \\
\hline Mining & & & & & & & & & & \\
\hline $\begin{array}{l}\text { Other } \\
\text { manufacturing } \\
\text { industries }\end{array}$ & & & & & & & & & & \\
\hline $\begin{array}{l}\text { Restaurants and } \\
\text { hotels }\end{array}$ & & & & $\begin{array}{l}>10 \\
\text { years }\end{array}$ & & & & & & \\
\hline Transportation & & & & & 5 years & $\begin{array}{l}>10 \\
\text { years }\end{array}$ & & & & \\
\hline Wholesale trade & & & & & & & & & & \\
\hline
\end{tabular}

\section{Conclusions}

Many companies may hide actual values of their impairment losses on goodwill, particularly during the financial crises in order to protect their stock value. Therefore, in this paper, we aim to analyze goodwill impairment for companies listed on the BIST 100 index for the years of 2008-2012, covering the recent financial crisis period and post-crisis period. Our paper helps the financial statement users in the assessment of disclosure quality under IAS 36, Paragraph 134d. Companies in the financial sector and holdings are excluded. There are 32 and 30 companies having goodwill accounts in 2008 and 2009 respectively. While in 2008, only eight of 27 firms have an effective disclosure about the method they have used in goodwill impairment. In 2009, information about methodology and at least about performing a goodwill impairment test has increased, but it is still limited and unfortunately, it did not allow any meaningful evaluation. In 2011, firms informing the test have increased to 19 out of 23. In 2012, the sample consists of 21 firms and 16 of them gave information about goodwill impairment. 
Key factors such as discount rates, growth rates, cash flow assumptions, and risk sensitivity analysis are main tools to understand goodwill reporting regime not only for selected companies and sectors but also for the country. In the financial crisis period, some firms used low discount rates, such as $6 \%$, in consumer trade industry. Since low discount rates will result in overestimated cash flow projections, the firms might avoid potential goodwill impairment losses. Growth rate disclosures, such as $5 \%$ and $6 \%$, are very optimistic disclosures especially in the financial crisis period. For the other years, there is a wide range in growth rate and discount rate assumptions. Furthermore, information about the period of cash flows is not enough and the years used in budget assumption are also higher than five years. According to the standard, when a period greater than five years is used for a cash-generating unit (group of units), an explanation of why that longer period is justified must be disclosed.

Briefly, insufficient disclosures on goodwill assessment and impairment including discount rates, growth rates, and the periods over which management has projected cash flows are found. This problem is important for investors considering the disclosure quality on goodwill assessment and for researchers examining the implication of IAS 36, regulators, and policy-setters. In line with ESMA (2013), in order to improve the overall disclosures provided by BIST companies, the following can be suggested: (1) disclosing the method instead of saying that "Goodwill impairment has been performed" and/or "There is no goodwill impairment indicator"; and (2) disclosing more information to be in compliance with IAS 36 about key assumptions (growth rate, discount rate, number of years used in budget, and cash flow assumptions). Further research may measure the effects of disclosure quality on stock prices.

\section{References}

Andrews, R. (2006). Impairment of assets: Measurement without disclosure? Research Report No. 92, the Association of Chartered Certified Accountants, London.

Carlin, T. M., \& Finch, N. (2011). Goodwill impairment testing under IFRS: A false impossible shore? Pacific Accounting Review, 23(3), 368-392.

Carlin, T. M., Finch, N., \& Ford, G. (2007). Goodwill impairment-An assessment of disclosure quality and compliance levels by large listed Australian firms. MGSM Working Paper No. 2007-8.

Elliott, J. A., \& Shaw, W. H. (1988). Write-offs as accounting procedures to manage perceptions. Journal of Accounting Research, 26, 91-119.

Ernst \& Young. (2011). IAS 36 impairment testing: Practical issues. Ernst \& Young. Retrieved from http://www.powertechexposed.com/IAS_36_impairment_testing_GL_IFRS.pdf

European Securities and Markets Authority [ESMA]. (2013). Review of the comparability and quality of disclosures. Retrieved from http:/www.esma.europa.eu/content/ESMA-Financial-institutions-must-improve-financial-statement-disclosures

Gurarda, S. (2015). Environmental management accounting. In Handbook of research on developing sustainable value in economics, finance, and marketing (Part of the Advances in Finance, Accounting, and Economics Book Series). Hershey, PA: IGI Global.

Holtzman, M. P., \& Sinnett, W. M. (2009). Goodwill impairments. Report of Director of Research Financial Executives Research Foundation and Duff \& Phelps.

Li, Z., Shroff, P. K., Venkataraman, R., \& Zhang, I. (2010). Causes and consequences of goodwill impairment losses. AAA 2005 FARS Meeting Paper.

$\mathrm{Xu}$, A., Anandaraja, W., \& Curatola, A. (2011). The value relevance of goodwill impairment. Research in Accounting Regulation, 23(2), 145-148.

Zucca, L. J., \& Campbell, D. R. (1992). A closer look at discretionary writedowns of impaired assets. Accounting Horizons, 6(3), $30-41$. 